\title{
For Felicitas
}

Jelle P. Baan

Krisis 41 (2): 116-119.

DOI

$10.21827 /$ krisis. 41.2 .38255

\section{Licence}

This work is licensed under a Creative Commons Attribution 4.0 License International License (CC BY 4.0). (C) 2021 The author(s). 


\section{For Felicitas}

Jelle P. Baan

Paragraph 135 of the Minima Moralia, in which Adorno draws our attention to the formal advantages of the "technical aid" of dictating for the dialectical procedure, could be read as an ode to Gretel. ${ }^{1}$ She was the one who helped during those first phases of writing by translating, as it were, his spoken words into written form. The advantage of this technique is that you can fall in the middle of the dialectic without having to worry that the burden of the beginning, in which you make naïve and ungrounded assumptions, will start to weigh as bad conscience later on. Because whoever starts dialecticizing will almost immediately realize that the dialectical movement had always already begun. How to catch up with the dialectic? Instead of being caught up in it, you want to be engaged in the dialectic, to participate in it.

The technique of dictating functions like a dialectical trampoline that allows the latecomer to arrive just in time by catapulting him directly towards that middle. Its paradoxical logic lets Adorno outwit the dialectic. For "dictation makes it possible for the writer, in the earliest phases of production, to maneuver himself into the position of critic", he explains. "What he sets down is tentative, provisional, mere material for revision, yet appears to him, once transcribed, as something estranged and in some measure objective. He need have no fear of committing something inadequate to paper, for he is not the one who has to write it [...] In face of the difficulty, now grown to desperate proportions, of every theoretical utterance, such tricks become a blessing" (\$ 135). By exteriorizing himself through Gretel, he does not have to feel the pain of those first torsions of dialecticizing. Before he has to put his thoughts on paper, he is first already his own second reader. She allows him to mediate immediately, and thus to begin in the middle. The middle of the beginning is posited or gesetzt by that first draft of the transcript which is both his own and not his own, as if he was his own souffleur. But this contradiction is immediately sublated and in that sense gets to the bottom of the text, to formulate it in Hegelian terms, because the transcripts reveals itself to be a palimpsest. This first version does not register the first moment of the dialectic, but the virtual trajectory before that. Thanks to their shared ruse Adorno is not the first of the dialectic, which is impossible, but the one before the first. Thinking after Hegel is for Adorno the heroic attempt to think before him. In that sense the dialectical trick of dictating, too, is a ruse of reason, but then one that wrestles itself from the magic circle of identity-thought. ${ }^{2}$ And that is precisely why “... thanks are due to the person taking down the dictation, if at the right moment [s] he pulls up the writer by contradiction, irony, nervosity, impatience and disrespect" (\$ 135).

As Müller-Doohm demonstrates in his biography, Adorno used to call this intensive dialectic between him and Gretel in those first phases of the writing process lämmergeieren. This is confirmed by the original German title of this fragment: Lämmergeier. "Why this word?", Müller-Doohm asks himself. As "a keen visitor to Frankfurt Zoo", he suggests, "he presumably saw lammergeiers or bearded vultures there (Gypaëtus barbatus). They feed mainly on carrion, but also on small mammals and birds. They are particularly partial to bones. Very large bones are dropped from a height onto rocks to 
break them; the marrow can then be devoured. This method of arriving at the kernel of a problem which at first appears too difficult or inaccessible, of 'cracking' it in order to extract its essence, may well have been the reason for choosing this word" (2005, 57). Combining this vital anecdote with Adorno's own interpretation of the activity of lämmergeieren reveals why any thinker who wants to taste the marrow of the dialectic can never work entirely alone. Even the Sprechstimme of the couple Teddy-Gretel is only the dominant voice in the contrapuntal composition of a philosophy in which the faculties enter into a new dissonant accord.

Adorno does not mention Gretel by name once in a fragment that seems entirely devoted to her ("thanks are due to the person..."). What interests him in this fragment is not so much his wife Gretel, but only her formal function as a transcriber in "cracking" the bones of the dialectic. More than a personal ode to Gretel then, this is a conceptual reconstruction of the remarkable role of what we could call the Felicitaseffect within the formal dynamics that keeps the chess-machine of negative dialectics running. The head of this thought-machine is not Adorno himself but Horkheimer. He is the director who administers the dialectic and keeps a close watch on its practical applicability. He plays the role of the Understanding. Adorno himself is the incarnation of Reason. He's the man of Ideas, and in that sense the very heart of the dialectic. This necessary division of labor is the secret behind what Adorno once described as their gemeinsame Existenz. And yet that shared existence is supported by even more intimate relations. Because the intuition of this dialectic falls apart in two uneven halves, which could never fit together, even though they do belong together: Felicitas and Detlef $\mathbf{3}$ (cf. Adorno and Benjamin 2014) which is to say Gretel Karplus and Walter Benjamin. They represent feeling and imagination, even if it would be impossible to separate the two, since they are always entangled. Only together they constitute the exact fantasy that according to Adorno is the organon of the ars inveniendi that philosophy should be (cf. Adorno 1977, 131). Gretel is the representative of the couple Detlef-Felicitas, while inversely Felizitas, as Benjamin wrote, is what binds Benjamin to Adorno and in a sense compensates for the latter's absence. Without their aid, Adorno would indeed remain a "Sorgenkind", a problem child, as Gretel frequently wrote in her letters to Benjamin (Müller-Doohm 2005, op. cit. 56). Whenever she wrote "be careful, T.W.A." in the margins of a transcribed manuscript this was from keeping their problem child of infinite reason to lose itself in the wild speculations that characterize the Ideenflucht of the dialectic.

The process that Adorno called lämmergeieren is the schematism of the dialectic. It is the soul of the dialectic. During this intensive process reason and intuition enter into direct contact and start to resonate; Adorno improvises and dictates, while Gretel makes notes, but also directly comments and sometimes even corrects him. ${ }^{4}$ The notes taken are so much more than a mere representation of what was said. What the transcript should capture are the traces of the dark precursor of the dialectic, ${ }^{\mathbf{5}}$ the "non-identical" that both animate it and keeps it moving, yet never finds its proper place within it. This primary torsion of the dialectic, its original twist so to say, forms an aberrant movement (cf. Lapoujade 2017), a "wavering, deviating line" (Adorno $\$$ 60) by which the whole vertiginous trajectory of his "unleashed" dialectic is intagliated. Only together were 
Teddy and Felicitas able to crack the biggest bone of the dialectic, Hegel's skull, in order to devour the marrow inside, the cerebrospinal fluid that is the lifeblood of this thought. What they crack by way of negative dialectics as a logic of disintegration is the skeleton of identity; the marrow which is released however, is the element of difference that nourishes their inventive schemas for tracing the aberrant movements of the non-identical that secretly animate this dialectic. Thus, the trick of dictating is the ruse of a metaschematism $^{6}$ in which the dialectic (Reason) and the aesthetic (Intuition) enter into an immediate union, temporarily short-circuiting the analytic (Understanding) ${ }^{7}$ Only together do they think those thoughts that do not comprehend themselves. ${ }^{8}$ And those thoughts alone are true, claims Adorno.

That's why thanks are due to Gretel-Felicitas. She operates as the organ of the non-identical that picks up on the traces of the differential element that precedes the dialectic. The Felicitas-effect is the direct mediation by which reason and the "exact imagination" (cf. Weber-Nicholsen 1997) produce schemas together that pick up on the perplexities of the non-identical. Only by exteriorizing himself through her and writing with her, could Adorno make the Ideas tangible. The irresistible charm of Felicitas is that she operates as an intercesseur (Deleuze 1990), a mediator that helps Reason orientate in thought, even in those distinct-obscure zones where the virtual spasms of the dialectic are almost imperceptible. It's in a very literal sense then that we should think of her as Adorno's ghostwriter that prefigured his thought, and allowed him to materialize the Ideas. Dialectics in its purest form.

\section{Notes}

1 Thanks are due to Gijs van Oenen for functioning as the head of my dialectic.

2 This idea of a Zauberkreis, a "magic circle" of identity-thought refers to a formulation used frequently by Adorno himself, cf. Adorno 2007, 145; $177 ; 406$.

3 Cf. Lonitz \& Gödde, 2014, 6: “In her correspondence with Benjamin, Gretel Karplus adopted this name which belonged to a figure from Wilhelm Speyer's play Ein Mantel, ein Hut, ein Handschuh [A Coat, a Hat, a Glove], in which Benjamin had been a collaborator".

4 This is alluded to in the fragment by Adorno himself: "... thanks are due to the person taking down the dictation, if at the right moment [italics added] he pulls up the writer by contradiction, irony, nervosity, impatience and disrespect".

5 For the dark precursor, cf. Deleuze 2004, $145,146$.
6 On metaschematism, cf. Deleuze 2004, 316. He discusses the term in relation to Leibniz who borrowed the term from Francis Bacon's Novum Organon.

7 I take this formulation directly from David Lapoujade who explains Gilles Deleuze's logic in these exact terms: "what characterizes transcendental empiricism is the immediate relation between aesthetic and dialectic, between the sensible and the Idea [...] There is in Deleuze only one aesthetic of intensities and one dialectic of ideas, and no more" (Lapoujade, 2017, 113). A similar, yet not the same, immediate relation between a dialectic of Ideas and an aesthetic of intensities is alluded to here.

8 "True are those thoughts alone that do not comprehend themselves" (\$ 122). 


\section{References}

Adorno, Gretel and Walter Benjamin. 2008. Correspondence 1930-1940. Edited by Henri Lönitz and Christoph Gödde. Translated by Wieland Hoban. Cambridge: Polity.

Adorno, Theodor. W. 1977. "The Actuality of Philosophy." Telos 31: 120-133.

Adorno, Theodor. W. 2005. Minima Moralia. London/ New York: Verso.

Adorno, Theodor. W. 2007. Negative dialectics. London: Continuum.

Deleuze, Gilles. 1990. Pourparlers. 1972 - 1990. Paris: Minuit.

Deleuze, Gilles. 2004. Difference and Repetition. London: Continuum.

Lapoujade, David. 2017. Aberrant Movements. The Philosophy of Gilles Deleuze. Los Angeles: Semiotext(e).

Müller-Doohm, Stefan. 2005. Adorno: A Biography Cambridge: Polity Press.

Weber-Nicholsen, Shierry. 1997. Exact Imagination, Late Work. Massachusetts: MIT Press.

\section{Biography}

Jelle P. Baan (1986) studied sociology and philosophy in Rotterdam and Paris and wrote Adorno, noch einmal. Een partituur voor esthetische theorie (2015, Klement). He's a Barthesian epigone who works on a mathesis singularis. His current research is focused on metaschematism, panoramic intelligence, late style, firstness, and what a soul is capable of. 